Article

\title{
A Systematic Literature Review on Integrative Lean and Sustainability Synergies over a Building's Lifecycle
}

\author{
Adrieli Cristina Vieira de Carvalho ${ }^{1}$, Ariovaldo Denis Granja ${ }^{1, *}$ (D) and Vanessa Gomes da Silva ${ }^{2}$ \\ 1 Construction Management Research Laboratory (LAGERCON), Department of Architecture and Building, \\ School of Civil Engineering, Architecture and Urban Design, University of Campinas (UNICAMP), \\ Campinas 13083-852, Brazil; adrieli.cv.carvalho@gmail.com \\ 2 Department of Architecture and Building, School of Civil Engineering, Architecture and Urban Design, \\ University of Campinas (UNICAMP), Campinas 13083-852, Brazil; vangomes@fec.unicamp.br \\ * Correspondence: adgranja@fec.unicamp.br; Tel.: +55-19-3521-2082
}

Academic Editor: Fabio Carlucci

Received: 14 May 2017; Accepted: 25 June 2017; Published: 2 July 2017

\begin{abstract}
The construction industry is increasingly moving towards the adoption of sustainable strategies and increased efficiency targets. Lean thinking (LT) aims at removing waste, increasing value, reducing costs, and improving the overall quality of products and processes. Sustainability, in turn, is concerned with the environmental, social, and economic impacts made by the construction industry. Both philosophies share efficient resource usage concerns. A systematic literature review (SLR) was carried out to cover the existing primary research and characterize its evolution and setting; to discuss the available empirical evidence to identify the LT and sustainability benefits and trade-offs; and to provide a holistic setting to promote those synergies. To catalyze the synergies between LT and sustainability, this paper highlights the potential application of LT elements throughout a building's lifecycle. Knowledge synthetized is helpful for decision-makers to understand and explore combinations of the performance-oriented LT philosophy for the provision of environmentally responsive buildings.
\end{abstract}

Keywords: lean thinking; sustainability; construction; systematic literature review; framework; lifecycle of buildings

\section{Introduction}

The recognition of the construction industry's role as a major contributor to global environmental impacts has increased the search for sustainable strategies and for environmentally responsive buildings. However, there is a need to outline some guidelines in order to ensure that construction projects will successfully reach expected results. Currently, sustainable strategies are often conditioned to the idea of environmental attributes being incorporated into construction [1]. The isolated adoption of sustainable strategies, such as using solar panels or green roofs, is often implemented through a green certification in a timely and conditioned way. As a result, this has created an interest among researchers to examine strategies to systemically incorporate sustainability.

Regarding sustainability, we consider the definition of sustainable construction, given by the International Council for Research and Innovation in Building and Construction (CIB), as the conception and development of a healthy construction process based on resource efficiency and ecological design. The CIB has defined seven principles for sustainable construction: reduce resource consumption, reuse resources, use recyclable resources, protect nature, eliminate rubbish, apply lifecycle costing, and focus on quality [2]. 
At the same time, organizations have also acknowledged the need for an approach that contributes not only to the production of sustainable buildings, but mainly for optimizing the delivery process and improving product quality as a whole. Lean Thinking (LT) is a potential approach for reaching those goals while reducing environmental loads.

Lean philosophy dates back to the development of the Japanese Toyota Production System (TPS) in 1940 [3]. To gain a competitive edge against the mass production of American companies after World War II, TPS examined the company's processes to eliminate waste, improve processes, and enable the faster and more efficient delivery of products.

These positive impacts have attracted interest to specific literature and to linking LT to environmental sustainability. These synergies are proven, since both approaches seek the reduction of waste and prioritize cleaner production. Moreover, companies that adopt continuous improvement tend to be more prone to implementing environmental practices [4]. Some researchers have explored aspects of this promising applied research field, and have reported benefits including waste and cost reduction, and environmental impact minimization, among others [5-12]. LT and sustainability are complements, and the adoption of lean production practices leads to the reduction of the marginal cost of environmental management and to the improvement of environmental performance [5]. Furthermore, lean and green concepts have in common additional attributes and synergies, such as waste and waste reduction techniques, people and organizations, lead time reduction, supply chain relationships, and key performance indicators (at a service level) [7,12].

The construction industry, in particular, lacks comprehensive research approaches to assist on how to combine LT and sustainability to address its economical, societal, and environmental concerns. As a matter of fact, few studies have depicted the synergies, benefits, and trade-offs between LT and sustainability in the construction industry [13-15], and the relevant insights that have been provided focused mostly on proposing and modeling relationships between the two concepts.

This paper systematically identifies LT-oriented elements that could be related to sustainability concepts throughout a building's lifecycle, and organizes them in a holistic framework to support the catalysis of potential synergies. Specifically, we aimed at: (i) identifying relevant previously published primary studies and categorizing them into the economic, social, and environmental dimensions of sustainability; (ii) discussing the available empirical evidence to recognize benefits, synergies, and trade-offs between LT and sustainable building; and (iii) providing a holistic framework to assist decision-makers on promoting those synergies.

We therefore carried out a systematic literature review (SLR) to identify fundamental scientific contributions to our research questions by revisiting published research that addresses similar or identical hypotheses. SLRs are valuable for presenting knowledge that is not likely to be obtained from the isolated reading of individual studies [16]. The synthesis capability resulting from combining SLR and a meta-analysis process enhances the reliability of a study's results [17].

Following this introduction, the study was divided into four parts. The next section describes our methodological approach. The third section is devoted to classifying the literature into specific research lines, and developing a conceptual framework for an integrative LT and sustainability approach. Finally, the results are discussed, with reference to the practices used to boost sustainability achievements and the gaps found in the literature. The conclusions focus on challenges that future research should address.

\section{Materials and Methods}

Our SLR process was carried out according to the following steps: (1) planning, (2) conducting the review, and (3) results reporting and dissemination [17] (Table 1). 
Table 1. Steps and phases of a systematic literature review (SLR).

\begin{tabular}{cc}
\hline \multirow{2}{*}{ Stage 1: Planning the review } & \multicolumn{1}{c}{ Identification of the need for a review } \\
\cline { 2 - 2 } & $\frac{\text { Preparation of a proposal for a review }}{\text { Development of a review protocol }}$ \\
\hline \multirow{2}{*}{ Stage 2: Conducting the review } & Sdentification of research \\
\cline { 2 - 2 } & $\frac{\text { Studection of studies }}{\text { Data extraction and monitoring progress }}$ \\
\hline \multirow{2}{*}{ Stage 3: Reporting and dissemination } & The report and recommendations \\
\hline & Source: [17].
\end{tabular}

\subsection{Planning the Review and Research Protocol}

The established SLR protocol comprised information on the objectives, sample articles, search strategy, and inclusion and exclusion criteria for performing the review. Our SLR began by selecting relevant keywords to characterize the scope of the study. Proper keyword choice is critical to composing the sample and ensuring that the search is complete and robust. Our choice was directed at identifying the previous research on the process of integrating LT and sustainability in the building sector. The databases selected for paper sampling were Compendex, ScienceDirect, Scielo, Scopus, and Web of Science. Preliminary search trials suggested that using specific keywords would excessively restrict the sample analysis. Thus, we simultaneously selected the key concepts with the highest number of studies potentially adherent to the subject: 'lean', 'sustain*' (to include 'sustainability' and its variations), and 'construction' (to limit the search to the construction industry).

\subsection{Conducting the Review}

The next step was data collection on the established state of the art to be defined: what is the topic set to be studied; what are the synergies and trade-offs highlighted in the integration of 'LT and sustainability'; how have these two themes been integrated into the construction sector; and what gaps and opportunities could be perceived.

Figure 1 shows the filtering process applied in the SLR sampling. Only papers published in journals and international conferences were included, whilst the exclusion criteria eliminated papers: (1) out of the construction industry scope; (2) not written in English, French, Portuguese, or Spanish; or (3) not jointly addressing the LT and sustainability concepts.

We then applied the 'snowball sampling' technique [18] to complement the sample. This is a non-probabilistic technique widely applied in qualitative and social studies, in which the initial participants of a study indicate new members until a certain goal is reached [19]. Appropriateness to theme and citation frequency within our initial sample guided the references' extended search.

Next, we performed a quality assessment procedure, using a ten-question checklist [20] (see Appendix A). Up to two points were assigned to each question, for a maximum possible score of twenty points per paper. Articles that scored less than fourteen points or scored zero in three or more questions were excluded, comprising a final sample of 48 articles (see Appendix B).

A database was subsequently created. The studies were then categorized into the triple bottom line [21] by using the following procedure:

- Analysis of the research's scope to identify the key aspects related to LT and sustainability in the construction sector;

- Grouping key aspects of a similar nature; and

- Grouping lines of research based on the interrelationships found. 


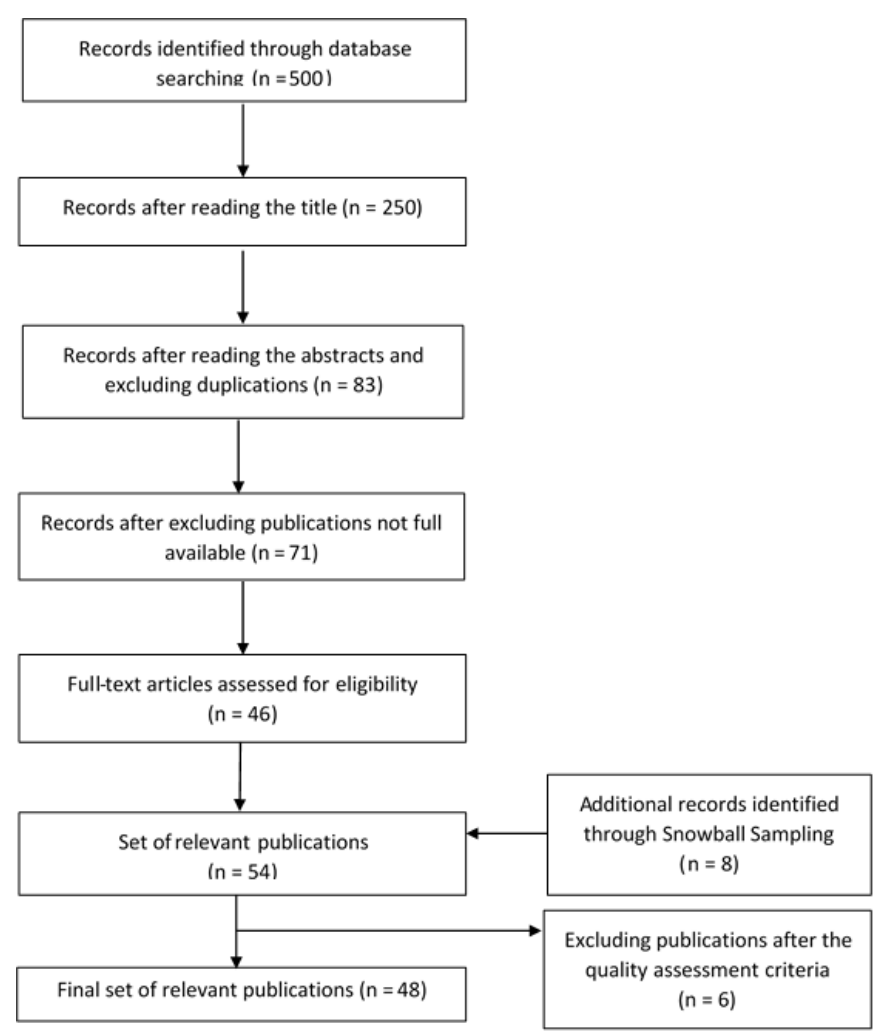

Figure 1. Filtering process applied in our SLR sampling.

\section{Results and Discussion}

\subsection{Descriptive Analysis of the SLR Findings}

The sample's analysis provided an overview about: (1) the distribution of studies over time; (2) the countries leading and concentrating research on the topic; and (3) the preferred research dissemination vehicles.

Figure 2 presents the number of the publications per year. Except for two articles published in 1998 and in 2002, publications bloomed after 2005 and peaked in 2012, for which nine studies were registered. This finding clearly ratified our assumption that the integration of the lean philosophy and sustainability is still poorly researched within the construction industry.

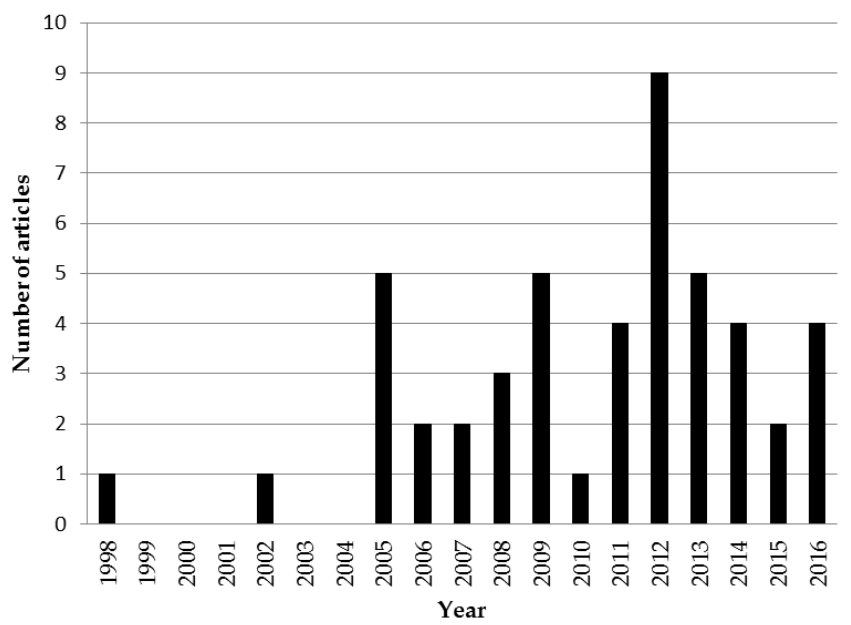

Figure 2. Number of publications per year, between 1998 and 2016. 
The United States clearly concentrates research in this subject: over $40 \%$ of the collected studies collected in our SLR were produced by US-affiliated authors (Figure 3). Australia, Brazil, the United Kingdom, Chile, and New Zealand follow the American lead, and together represent 37\% of published studies.

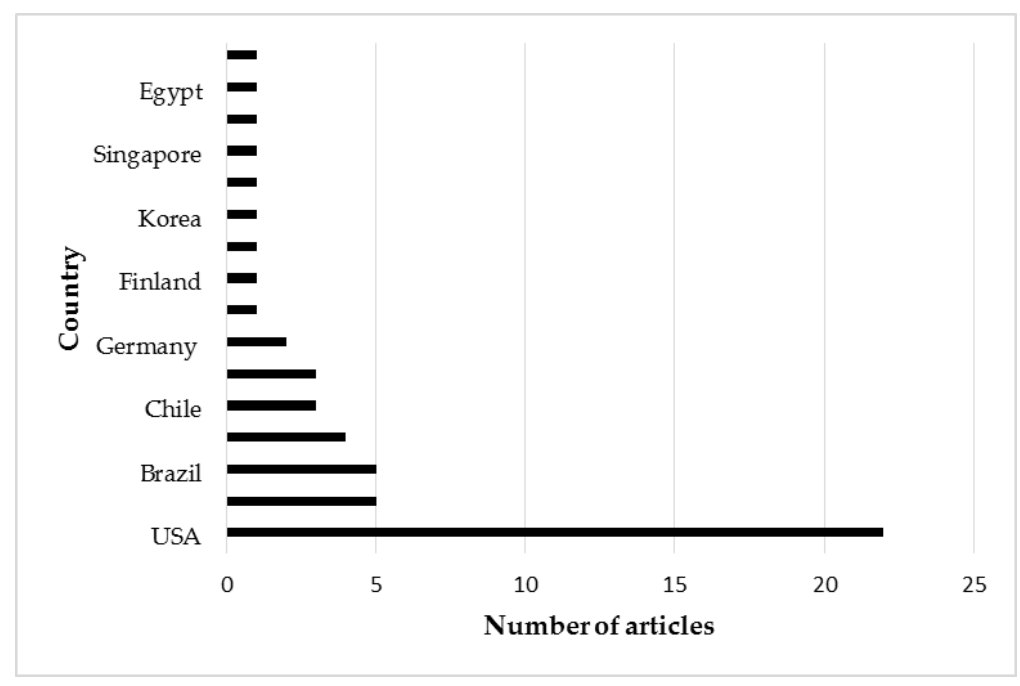

Figure 3. Geographical distribution of studies.

The International Group for Lean Construction (IGLC), dedicated to improving processes and Architecture, Engineering and Construction (AEC) products based on the Lean Production philosophy, promotes a solid conference series which explains their prevalence over journal publications (Figure 4).

目Journal Articles $\square$ Conference Articles

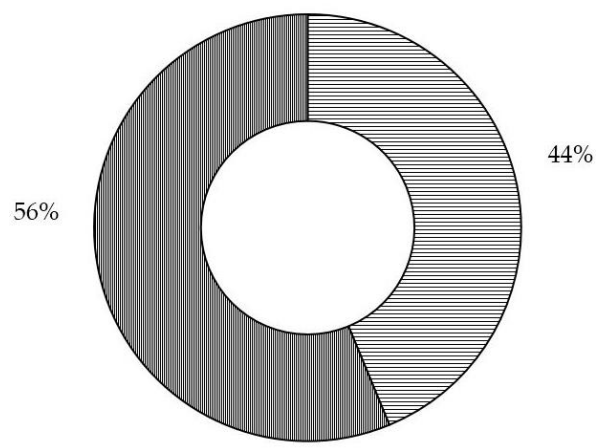

Figure 4. Journal-to-conference publication ratio of the SLR sample.

\subsection{Lean and Sustainability Synergies}

To recognize patterns and synergies in the evidence base, we first identified studies that support the integration between LT and sustainability or that suggested a conditional relation between these concepts. Next, we categorized the research topics according to the sustainability triple bottom line, i.e., financial influence; human well-being; and environmental interactions resulting from the sustainable building delivery process.

\subsubsection{Environmental Sustainability}

Earlier research has already established a complementary and synergistic relationship between LT and sustainability in the construction sector [13,14,22-24]. Lean and green adopters have in 
common the pursuit of delivering high performance projects that focus on waste reduction, value delivery, and cost reductions [13]. Answers about how the adoption of lean tools and methods affects the construction and operation of green facilities were provided by [14], whereas the interactions between green guidelines for construction, considering green building certification criteria and Lean Construction (LC) principles, were outlined in [23]. As reported in [24], the use of lean principles also made it possible for a Leadership in Energy and Environmental Design (LEED) certificate building to cost no more than a conventional building with similar characteristics [24]. Moreover, these studies have shown that lean principles act as catalysts to improve sustainability attributes. Most notably, LT and sustainability share a common focus on waste reduction, despite differing in their emphases [25]. While lean principles focus on process waste reduction and maximum value generation, sustainability addresses resource minimization, systems optimization, and wasteful construction practices [26].

The empirical evidence also shows that LT and sustainability are congruent as to eliminating non-value-generating activities, which would unnecessarily increase environmental impacts [27]. For example, reducing superfluous material usage reduces energy consumption and generates less waste. Despite this, eliminating what LT considers waste does not necessarily result in improved environmental performance [28]. Although LT indeed creates opportunities to boost sustainability, the difficulty in understanding and quantifying the impacts of LC methods hampers its acceptance by stakeholders [14].

Whist no significant relation between LT and environmental performance was reported by [29], other studies argue that LT can be actually detrimental to it $[14,30,31]$. Examples include just-in-time production, which allows contractors to minimize buffers [32] and reduce the various sources of extra inventory, but may increase volatile organic compounds and $\mathrm{CO}_{2}$ emissions due to the frequent transport of inventory and materials [14]. On the positive side, adopting green practices typically increases the initial budget, but LT applications in construction may positively counteract to reduce waste-related costs [33]. Since the lean philosophy ultimately aims at delivering value to the customer, [28] highlighted a conditional relationship: LT does not always result in positive environmental impacts, but can rather contribute to achieve sustainability goals, whenever this is perceived as valuable.

\subsubsection{Economic Sustainability}

Green certification costs are one of the barriers to building more sustainably. The captured studies on the subject stated that certifications costs ranged from 0 to $21 \%$ [34]. We identified some relevant studies concerned with investigating the relationship between the costs of conventional buildings and more sustainable buildings [35-40]. The economic and financial aspects of green buildings have been covered [36], however the positive association of green attribute investment with the increase of building costs has been challenged [40]. With similar purposes, some research initiatives already identify LC methods as enablers of initial cost reduction and waste elimination [33,41,42]. Sustainability efforts have correlated with the reduction of building waste, thus yielding cost savings [33]. Integrated design and detailing competencies were also recognized as drivers of first cost savings and operating efficiency improvements [41].

The reviewed literature also showed some opportunities to simultaneously improve the construction process and minimize its associated costs. For example, Value Stream Mapping (VSM) is an important tool to make the construction process more transparent and to improve the process of production by working to eliminate economic waste [28]. Kaizen—the Japanese term for 'continuous improvement' - is another resourceful lean practice tool for pursuing sustainable values, not only for social and environmental purposes, but also for economic ones [28]. Target Costing (TC), a lean method used in the construction industry to allocate the construction budget to areas or functions that are most valued by the costumers, is only examined for sustainability purposes by [34], who mostly discuss the green premium associated with sustainable buildings. The TC method should be used to prevent an unnecessary increase in facility performance and resource wastage by pre-defining functions, capacities, and specifications [28]. 
Explicit references on how to achieve successful and economically sustainable facilities have not yet been identified in the literature. In fact, one study found that the cost of green practices brought an increase of $1.32 \%$ in the initial budget, whilst the lean savings represented a $0.19 \%$ cost reduction [33]. Despite the cost reduction being unrepresentative in relation to the total cost of the project (around $14 \%$ of the green building certification investment), the savings considered reducing the materials losses only. Therefore, one might infer that completely analyzing the lean applications would result in higher savings.

\subsubsection{Social Sustainability}

The social dimension of sustainability is possibly the major factor within the construction industry. Within the construction chain, three stakeholder groups bear different values: owners, users, and society. However, social aspects are usually considered only if they are requested by the owners or by the one who pays for certain requirements. As a result, interests from the society perspective are often not taken into account.

In this regard, the aspect that has received the greatest attention is the potential given by the lean perspective to expand the typical customer-focused perspective to cover broader aspects, and to focus on value generation to society [42,43] perceived as an expanded idea of the 'potential customer'. The possibility of developing a construction strategy that delivered value to society was demonstrated through a case study of social housing projects in Chile [43].

It is also difficult to measure the social impacts of facilities on humans [28]. In this sense, some studies show, through lean practices, how it is possible to not only consider social impact but also measure it $[15,27,43-45]$ through matrix and checklist techniques to address the evaluation of lean, green, and wellbeing actions at building sites [45]. A matrix correlates social, environmental, and economic indicators to LC principles to exemplify sustainable processes' management contributions to a society and economy [15]. These studies show how LC as a practice focused on social responsibility, and when committed to the work environment can potentially fill gaps that sustainable practices alone are unable to cover.

\subsubsection{Synergies Found between LT and Sustainability}

This study registered forty-six synergies found in the reviewed literature, clustered in accordance with the triple bottom line of sustainability (Table 2).

Table 2. Lean and sustainability synergies: environmental, economic, and social dimensions.

\begin{tabular}{cl}
\hline Sustainability Dimensions & \multicolumn{1}{c}{ Main Synergy } \\
\hline \multirow{2}{*}{ Environmental } & $\begin{array}{l}\text { Reduced waste; reduced energy consumption; reduced water usage; reduced carbon } \\
\text { emission; reduced environmental impacts; improvement in sustainable innovation; } \\
\text { improvement in environmental quality; contributes to a holistic view of sustainability } \\
\text { issues; increased energy efficiency; material recycling; greater ecological credibility. }\end{array}$ \\
& $\begin{array}{l}\text { Reduced cost and lead time; increased productivity; increased constructability; } \\
\text { avoided design "busts" for a facility; reduced risk of rework and/or subpar facility } \\
\text { performance; reduced inventory related cost; reduced initial costs; increased } \\
\text { sustainable competitive advantage; improved corporate image; improved process flow; } \\
\text { increased compliance with customers expectation; optimized resource usage; process } \\
\text { optimization; continuous improvement; improved building performance; reduced } \\
\text { process variability; breaking barriers; improved product; improved decision-making } \\
\text { process; increased value creation; increased flexibility and adaptability; eased } \\
\text { compliance with the requirements for maintenance; increased reliability of facilities; } \\
\text { improved quality; transparency. }\end{array}$ \\
\hline & $\begin{array}{l}\text { Improved health and safety working environment; increased employee morale and } \\
\text { commitment; work environment clean and organized; improved workflow; } \\
\text { minimization of conflicts; improved social performance; local development; enhanced } \\
\text { relationship with community; improved relationship among stakeholders; wellbeing. }\end{array}$ \\
\hline Social &
\end{tabular}




\subsection{Reported Integration between Lean and Sustainability}

Most studies focused on the integration of LT and sustainability referred to building design or construction, with a clear shortage of information on the remaining life cycle stages. The construction phase, when wastes are measurable and tangible [15], was particularly emphasized. These outcomes are understandable, since the lean philosophy was devised in the manufacturing environment, and the terms 'Lean Production' and 'Lean Manufacturing' obviously target the production phase. LT-inspired tools developed for the construction industry were therefore naturally directed to design and construction ('Product' stage) problem-solving, and the 'Use' and 'End of life' stages remain uncovered.

Some studies tried to insert sustainability into the lean concept to integrate their benefits. Recently, more studies have introduced the environment as a lean customer $[22,25,26]$. They discuss how to achieve sustainability and at the same time guarantee value for the various construction stakeholders and the environment.

An empirical study compared LC principles with building performance criteria embedded in LEED NC ${ }^{\circledR}$, one environmental rating system [23]. Although both concepts reduce waste and encourage improvements to buildings, the low interaction found $(12.68 \%)$ is influenced by the conceptual differences between the environmental rating system and LC. For example, the normative character of the certification tool does not allow the flexibility valued by LC. Moreover, LEED NC ${ }^{\circledR}$ does not focus on improving processes, working conditions, and safety during building conception and construction. These two philosophies can be yet used in a complementary manner to improve building delivery processes [23].

The authors in [15] also proposed a matrix based on the eleven principles of lean proposed by [46] in his report to the Center for Integrated Facility Engineering (CIFE), as well as the sustainability indicators and guidelines for the processes of organizations published by Global Reporting Initiatives (GRI). The findings showed that sustainability has an impact on lean principles [15]. Despite the low interaction (13.5\%) between LC principles and sustainability indicators, the study recognizes a common agenda in improving processes, reducing wastes, continuous improvement, and marketing issues [15]. The authors also highlight the importance of setting sustainable goals that go beyond environmental initiatives towards social and economic sustainability [15].

One study shows that construction industry professionals believe that lean and sustainability are different, not simply relatable, approaches [47]. The interviewees stated that the two concepts can be applied together, but it is not a synergistic relationship. Conversely, a study on the application of lean, green, and wellbeing principles in site layout managing pointed out that integrated management actions improved sustainability by $79 \%, 64 \%$, and $49 \%$ in the cases studied [45].

\subsection{Integrative Framework Definition}

After reporting results on the synergies and trade-offs in the integration between LT and sustainability in the construction industry, we proceeded with an SLR result extraction to structure our conceptual framework depicting 'LT and sustainability' integration.

Six synergies were most frequently cited in the reviewed studies: (i) waste reduction; (ii) reduced cost and lead-time; (iii) increased value creation; (iv) optimized resource use; (v) reduced energy consumption; and (vi) improved health and safety (Figure 5). Waste reduction was the most cited synergy, corroborating results from [48], which surveyed the UK's construction sector professionals. However, is important to mention that, from the lean perspective, 'waste reduction' refers to reducing and/or eliminating activities that do not add value to the customer, while from the sustainability point of view, it is related to resources savings.

As to distribution of LT elements across the literature sample, Prefabrication [17 mentions], Value stream mapping and Just-in-time [11 mentions each], and Kaizen [10 mentions] had the highest occurrence frequencies registered by the SLR (Figure 6). 


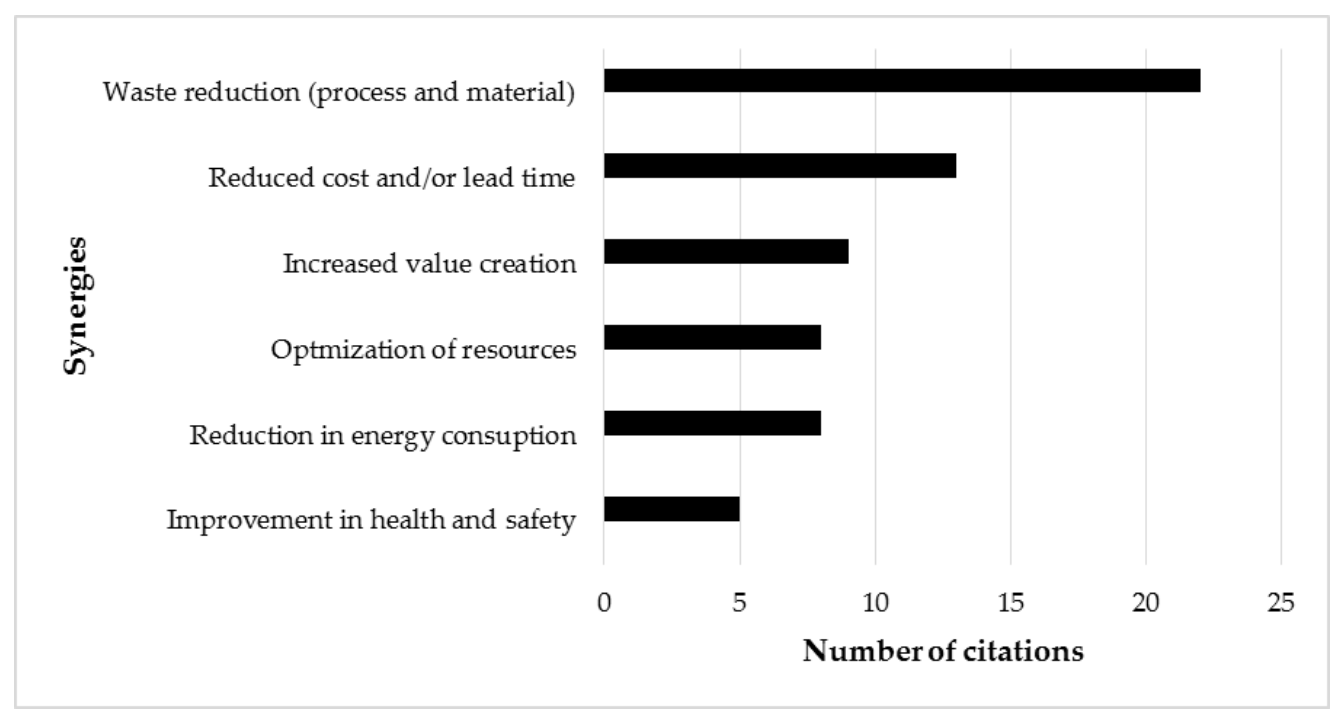

Figure 5. Synergies most frequently found in the SLR.

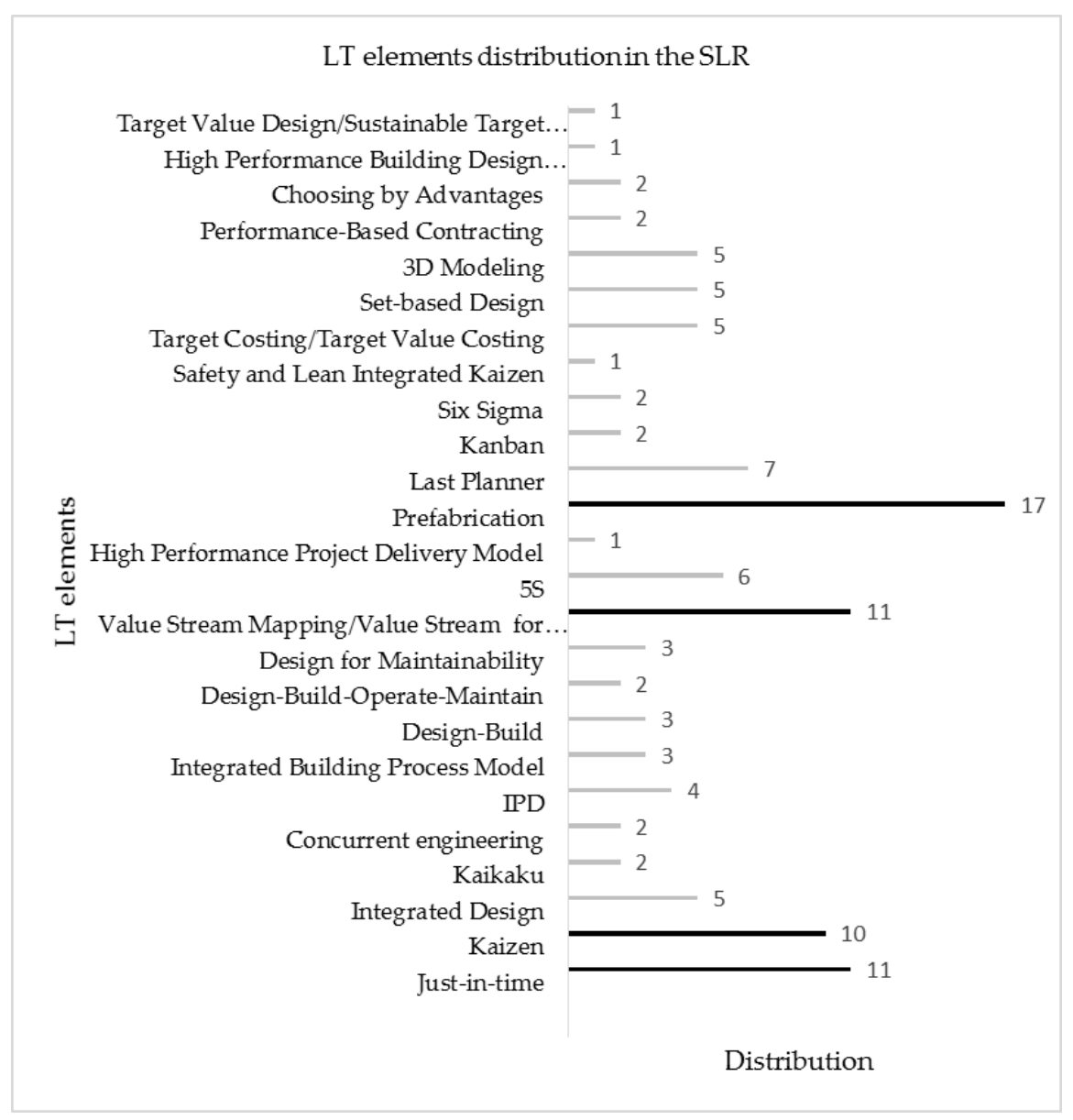

Figure 6. Distribution of Lean Thinking (LT) elements in the literature reviewed (48 papers). Whenever a paper mentioned multiple elements, all of them were computed and totalized 115 mentions.

We then created a lifecycle map of the principles, tools, methods, and methodologies (here simply referred to as 'LT element') used in the literature, to evaluate how they interact over the lifecycle stages of a building. LT and sustainability approaches were originally developed in distinct fields 
of study and practice, with proper forms of classification and application. They, therefore, address the construction flows differently. A traditional life cycle process can be divided, for example, into pre-design, schematic design, design development, construction documents, bidding, construction, closeout, and operation [49]. The lean philosophy, in turn, looks at construction from business, design, job site, supply, and maintenance flows perspectives [50]. Given these varied approaches, for an appropriate mapping of an integrative tool application, we adopted the definition according to [51], as follows:

- Product stage: encompasses all steps relating to the product development phase with regard to the raw material supply, transport, and manufacturing;

- Design process: includes planning, managing, pre-design, schematic design, design development, conceptualization, criteria design, and detailed design activities;

- Construction process: covers all activities of planning, managing, transportation, supply, installation, assembly, construction, and operation;

- Use stage: use, maintenance, repair, replacement, and refurbishment activities;

- End of life stage: includes activities related to demolition, transportation, waste processing, and disposal.

Based on the top six synergies most frequently cited in our review (Figure 5), we shaped our findings into a framework, which delivers a holistic and integrative perspective on current LT and sustainability (Figure 7).

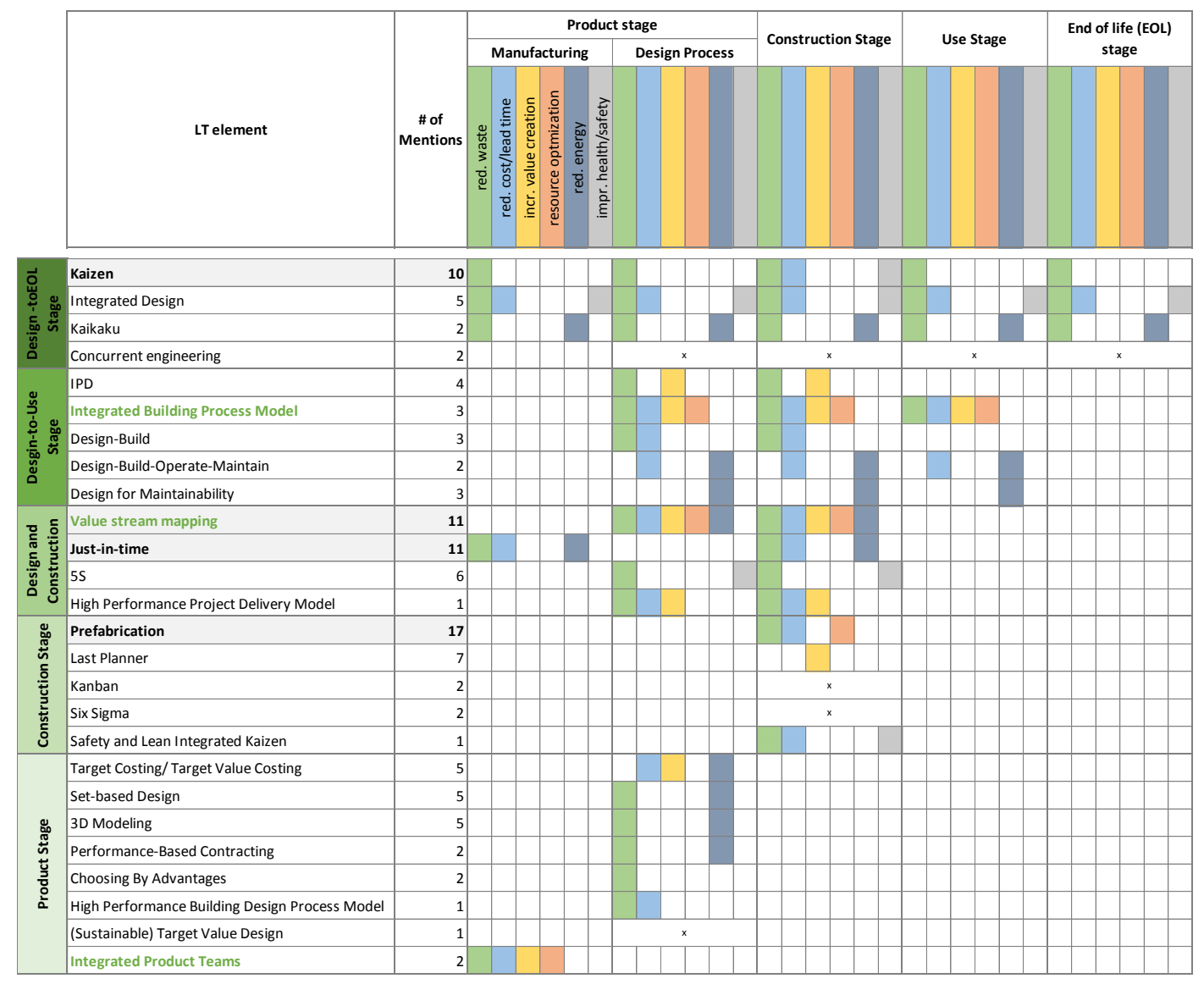

Figure 7. Lifecycle mapping of LT elements along a building's lifecycle, considering the top six synergies found in the SLR: waste reduction (process and materials); reduced cost and/or lead time; increased value creation; resource optimization; reduced energy consumption; and improved health and safety. For reference purposes, ' $x$ ' represents elements related to less frequently mentioned synergies. 
The framework is aimed at assisting decision-makers in AEC companies to choose the most appropriate LT elements for optimizing sustainability results in the targeted building's lifecycle stage, based on the reported research evidence. Nonetheless, our framework valuably organizes information and clarifies several key points. Firstly, five groups of instruments were clearly defined, based on their coverage of a building's lifecycle (Figure 7): (1) Product stage only; (2) Construction stage only; (3) the Design and Construction stages; (4) the Design to Use stages; and (5) the Design to End of Life (EOL) stages. The LT elements most comprehensive in terms of their span within a building lifecycle were 'Just-in-time', 'Kaizen', 'Integrated design', 'Kaikaku', and 'Concurrent Engineering'. Despite the latter's potential to be applied in most of the lifecycle, it received little attention from the literature.

Secondly, the LT elements most complete in scope, covering at least four out of the six most frequent synergies, were 'Integrated product teams, 'Value stream mapping', and 'Integrated Building Process Model'. Finally, the LT elements most cited in the reviewed literature were 'Prefabrication', 'Value stream mapping', 'Just-in-time', and 'Kaizen'. This means that: (i) except for 'Value stream mapping', the most used LT elements are actually the least complete in scope; (ii) those elements that span along the lifecycle do so by exploring a fraction of the needed interaction with sustainable building goals; and (iii) a combination of elements covering the product and EOL stages, with others emphasizing the design and construction (e.g., 'Value stream mapping') and design-to-use stages (e.g., 'Integrated building process model'), can maximize the benefit of applying LT to catalyze sustainable building qualities.

By mapping the LT elements adopted by the construction industry, we also confirmed our assumption that the use and end of life stages have substantial room for improvement, and have so far been covered by few elements, which are incomplete in scope and cover no more than three potential synergies at a time. A second group of elements is less comprehensive regarding lifecycle stages, but is more robust in scope. The 'Integrated building process model' is more complete but less mentioned, possibly for being a promising, relatively novel practice with a high difficulty level of implementation. Conversely, 'Value stream mapping' is very complete and frequently mentioned in the literature, which suggests it might be gaining traction in construction applications. It could be combined with specific elements dedicated to the health/safety concerns left uncovered.

\section{Conclusions}

The main motivation of this paper was to seek synergies between LT and sustainability, considering the lifecycle of buildings. As in any study, our research work is not exempt from limitations. The main restriction relates to the realization of SLR itself, since the process of refining studies, inclusion criteria, and sources of exclusion are not immune to subjectivity and bias. However, the SLR synthesis provided a new and more comprehensive perspective on the subject, which were not achievable from the appraisal of the results of each study in isolation.

Prior works have focused mostly on identifying LT and sustainability benefits, synergies, and trade-offs. Our framework provides a holistic view of LT and sustainability integration to assist decision-makers in the construction industry. To our knowledge, this is a novel study, which advances the prescription of LT elements as catalysts of sustainability over a building's lifecycle according to synergies identified in published evidence.

We found that the published studies have different positions about the integration and synergies between LT and sustainability concepts. However, most papers converge over the idea that LT and sustainability focuses on waste reduction and maximum value generation. Other studies show that adopting LT elements does not necessarily improve and may even harm environmental performance. These contradictions might be explained by the fact that sustainability is strongly influenced by decisions made during conception and design, while LT has still mainly focused on the construction stage of projects by the prescription of lean techniques and tools. Another possible explanation stems from the fact that LT-oriented customers have sometimes a different mindset compared to sustainability-oriented ones. While LT focuses on meeting the customer's values 
whatever they may value, the sustainability envisions value generation to society, perceived as a broader potential customer.

The evaluation of previous work also shows a gap in research about the social and economic lines of inquiry. Key social performance metrics are needed to provide opportunities for impoverished communities. In the economic area, the full potential of LT should be explored to ensure a profit margin while at the same time delivering sustainable value to the customer.

Our findings from SLR were synthesized in a holistic framework that makes easy an understanding of the applications, potential improvements, and fields to explore regarding the synergies between LT and sustainable buildings. The framework valuably organizes the information and clarifies key points, such as the fact that the most used LT elements are actually the least complete in scope. Finally, it can guide and facilitate selecting the most appropriate LT element or combination of instruments for targeted lifecycle stage(s).

Acknowledgments: This research is supported by the National Council for the Improvement of Higher Education (CAPES).

Author Contributions: Adrieli Cristina Vieira de Carvalho is the leading author of this study, and developed the content of the manuscript. Ariovaldo Denis Granja contributed significantly to the structure and review of the manuscript, and Vanessa Gomes da Silva contributed significantly to the content, structure, and review of the manuscript. All authors carefully read and approved the final version of the manuscript.

Conflicts of Interest: The authors declare no conflict of interest.

\section{Appendix A}

Table A1. Checklist for quality assessment criteria.

\begin{tabular}{cr}
\hline Number & Question \\
\hline 1 & How credible are the findings? If credible, are they important? \\
\hline 2 & How well does the evaluation address its original aims and purpose? \\
\hline 3 & How defensible is the research design? \\
\hline 4 & How well defined are the sample design/target selection of cases/documents? \\
\hline 6 & How well was data collection carried out? \\
\hline 7 & How well are the contexts and data sources retained and portrayed? \\
\hline 9 & How clear are the links between data, interpretation and conclusions-i.e., how well can \\
\hline 10 & the route to any conclusions be seen? \\
\hline & How clear and coherent is the reporting? \\
\hline
\end{tabular}

\section{Appendix B}

Table A2. The 48 papers composing the final SLR sample.

\begin{tabular}{l}
\hline \multicolumn{1}{c}{ Papers } \\
\hline Ahuja, R. Sustainable construction: Is lean green? In Proceedings of International Conference on Sustainable Design, \\
Engineering, and Construction, Fort Worth, TX, USA, 7-9 November 2012; American Society of Civil Engineers \\
(ASCE): Reston, VA, USA, 2013; pp. 903-911. \\
\hline Arroyo, P.; Tommelein, I. D.; Ballard, G. Deciding a sustainable alternative by 'choosing by advantages' in the \\
aec industry. In Proceedings of 20th Annual Conference of the International Group for Lean, San Diego, USA, \\
18-20 July 2012. \\
\hline Bae, J.W.; Kim, Y.W. Assessing the environmental impacts of lean supply system: A case study of rebar supply \\
in high-rise condominium construction projects. In Proceedings of construction Research Congress, Seattle, CD, \\
USA, 5-7 April 2009, American Society of Civil Engineers (ASCE): Reston, VA, USA, 2009; pp. 1009-1018. \\
\hline
\end{tabular}


Table A2. Cont.

\begin{tabular}{|c|}
\hline Papers \\
\hline $\begin{array}{l}\text { Bae, J.W.; Kim, Y.W. Sustainable value on construction projects and lean construction. J. Green Build. 2008, 3, } \\
\text { 155-167. Available online: http:/ / www.scopus.com/inward/record.url?eid=2-s2.0-77953336155\& } \\
\text { partnerID=40\&md5=3eda2cd491661864136f1579c80c0ded (accessed on } 10 \text { February 2016). }\end{array}$ \\
\hline $\begin{array}{l}\text { Enache-Pommer, E.; Horman, M. Greening of healthcare facilities: Case studies of children's hospitals. } \\
\text { In Proceedings of Architectural Engineering Conference (AEI), Denver, CO, USA, 24-27 September 2008, } \\
\text { American Society of Civil Engineers (ASCE): Reston, VA, USA, 2008, pp. 1-10. }\end{array}$ \\
\hline $\begin{array}{l}\text { Carneiro, S.B.M.; Campos, I.B.; Oliveira, D.M.; Barros Neto, J.P. Lean and green: A relationship matrix. } \\
\text { In Proceedings of 20th Annual Conference of the International Group for Lean, San Diego, USA, 18-20 July } 2012 .\end{array}$ \\
\hline $\begin{array}{l}\text { Castro-Lacouture, D.; Ospina-Alvarado, A.M.; Roper, K.O. AEC+P+F integration with green project delivery } \\
\text { and lean focus. J. Green Build. 2008, 3, 154-169. Available online: http:/ / www.scopus.com/inward/record.url? } \\
\text { eid=2-s2.0-77953332834\&partnerID=40\&md5=df67cdbc42d53307d2ca46551864be5e (accessed on } 9 \text { July 2016). }\end{array}$ \\
\hline $\begin{array}{l}\text { Dahl, P.K.; Horman, M.J.; Riley, D.R. Lean principles to inject operations knowledge into design. } \\
\text { In Proceedings of 20th Annual Conference of the International Group for Lean Construction, San Diego, CA, } \\
\text { USA, 18-20 July 2012, pp. 431-436. }\end{array}$ \\
\hline $\begin{array}{l}\text { Degani, C.M.; Cardoso, F.F. Environmental Performance and Lean Construction Concepts: Can We Talk about } \\
\text { A 'Clean Construction'. In Proceedings of 10th Annual Conference of the International Group for Lean } \\
\text { Construction, Gramado, Brazil, 6-8 August 2002, pp. 1-12. }\end{array}$ \\
\hline $\begin{array}{l}\text { Enache-Pommer, E. et al. A unified process approach to healthcare project delivery: Synergies between } \\
\text { greening strategies, lean principles and BIM. In Proceedings of Construction Research Congress, Banff, Alberta, } \\
\text { Canada, 8-10 May 2010, American Society of Civil Engineers (ASCE): Reston, VA, USA, 2010, pp. 1376-1385. }\end{array}$ \\
\hline $\begin{array}{l}\text { Enache-Pommer, E.; Horman, M. Key processes in the building delivery of green hospitals. In Proceedings of } \\
\text { Construction Research Congress, Seattle, CD, USA, 5-7 April 2009, American Society of Civil Engineers (ASCE): } \\
\text { Reston, VA, USA, 2009, pp. 636-645. }\end{array}$ \\
\hline $\begin{array}{l}\text { Enache-Pommer, E.; Horman, M. Greening of healthcare facilities: Case studies of children's hospitals. } \\
\text { In Proceedings of Architectural Engineering Conference (AEI), Denver, CO, USA, 24-27 September 2008, } \\
\text { American Society of Civil Engineers (ASCE): Reston, VA, USA, 2008, pp. 1-10. }\end{array}$ \\
\hline $\begin{array}{l}\text { Golzarpoor, H.; González, V. A Green-Lean Simulation Model for Assessing Environmental and Production } \\
\text { Waste in Construction. In Proceedings of 21th Annual Conference of the International Group for Lean } \\
\text { Construction, Fortaleza, Brazil, 31-2 August 2013, pp. 885-894. }\end{array}$ \\
\hline $\begin{array}{l}\text { Horman, M.J.; Riley, D.R.; Lapinski, A.R.; Korkmaz, S.; Pulaski, M.H.; Magent, C.S.; Luo, Y.; Harding, N.; } \\
\text { Dahl, P.K. Delivering green buildings: Process improvements for sustainable construction. J. Green Build. 2006, } \\
\text { 1, 123-140. Available online: http:// www.scopus.com/inward/record.url?eid=2-s2.0-33646746735\& } \\
\text { partnerID=40\&md5=a530c0a1d5df35972714341f693ff6fd (accessed on } 10 \text { February 2016). }\end{array}$ \\
\hline
\end{tabular}

Huovila, P.; Koskela, L. Contribution of the principles of lean construction to meet the challenges of sustainable development. In Proceedings of 6th Annual Conference of the International Group for Lean Construction, Guarujá, Brazil, 13-15 August 1998, pp. 1-11.

Jacomit, A.M.; Silva, V.G.; Granja, A.D. Can sustainable buildings cost the same as conventional buildings? In Proceedings of 3rd CIB International Conference on Smart and Sustainable Built Environments, Delft, The Netherlands, 15-19 June 2009, pp. 1-8.

Johnsen, C.A.; Drevland, F. Lean and sustainability: three pillar thinking in the production process. In Proceedings of Annual Conference of the International Group for Lean Construction, Boston, MA, USA, 2016, pp. 23-32.

Khodeir, L.M.; Othman, R. Examining the interaction between lean and sustainability principles in the management process of AEC industry. Ain Shams Eng. J. 2016, 1-8. Available online: http:/ / www.sciencedirect.com/science/article/pii/S2090447916301769 (accessed on 20 January 2017).

Klotz, L.; Horman, M. Transparency, process mapping and environmentally sustainable building projects. In Proceedings of Annual Conference of the International Group for Lean Construction, East Lansing, MI, USA, 2007, pp. 322-331. 
Table A2. Cont.

\begin{tabular}{l}
\hline \multicolumn{1}{c}{ Papers } \\
\hline Koranda, C.; Chong, W.K.; Kim, C.; Chou, J-S; Kim, C. An investigation of the applicability of sustainability \\
and lean concepts to small construction projects. KSCE J. Civil Eng. 2012, 16, 699-707. Available online: \\
http:/ /www.scopus.com/inward/record.url?eid=2-s2.0-84863315168\&partnerID=40\&md5= \\
94abac4a94a51a106Z40c33eaef190666 (accessed on 12 March 2016). \\
\hline Lapinski, A.; Horman, M.; Riley, D. Delivering sustainability: Lean principles for green projects. In Proceedings \\
of the Construction Research Congress, San Diego, CA, USA, 5-7 April 2005; American Society of Civil Engineers: \\
Reston, VA, USA, 2012, pp. 53-62. \\
\hline Lapinski, A.R.; Horman, M.J.; Riley, D.R. Lean processes for sustainable project delivery. J. Constr. Eng. Manag. \\
2006, 132, 1083-1091.
\end{tabular}

Luo, Y.; Riley, D.R.; Horman, M.J. Lean principles for prefabrication in green design-build (GDB) projects. In Proceedings of 13th Annual Conference of the International Group for Lean Construction, Sydney, Australia, 2005, pp. 539-548.

Magent, C.S.; Riley, D.R.; Horman, M.J. High performance building design process model. In Proceedings of 20th Annual Conference of the International Group for Lean Construction, San Diego, CA, USA, 2012, pp. 817-826.

Maris, K.; Parrish, K. The confluence of lean and green construction practices in the commercial buildings market. In Proceedings of Annual Conference of the International Group for Lean Construction, Boston, MA, USA, 20-22 July 2016, pp. 43-52.

Martinez, P.; González, V.; Fonseca, E. Integración conceptual Green-Lean en el diseño, planificación y construcción de proyectos. Rev. Ing. Construcc. 2009, 24, 05-32. Available online: http:/ / www.scielo.cl/scielo.php?script=sci_arttext\&pid=S0718-50732009000100001 (accessed on 10 March 2016).

Nahmens, I.; Ikuma, L.H. Effects of lean construction on sustainability of modular homebuilding. J. Archit. Eng. 2012, 18, 155-163. Available online: http:/ / ascelibrary.org/doi/abs/10.1061/(ASCE)AE.1943-5568.0000054 (accessed on 12 March 2016).

Nahmens, I. From lean to green construction: A natural extension. In Proceedings of Construction Research Congress, Seattle, CD , USA, 5-7 April 2009, American Society of Civil Engineers (ASCE): Reston, VA, USA, 2009, pp. 1058-1067.

Novak, V.M. Value paradigm: Revealing synergy between lean and sustainability. In Proceedings of 20th Annual Conference of the International Group for Lean, San Diego, CA, USA, 18-20 July, 2012.

Ochoa, J.J. Reducing plan variations in delivering sustainable building projects. J. Clean. Prod. 2014, 85, 276-288. Available online: http://www.sciencedirect.com/science/article/pii/S0959652614000377 (accessed on 10 March 2015).

Ogunbiyi, O.; Oladapo, A.; Goulding, J. An empirical study of the impact of lean construction techniques on sustainable construction in the UK. Constr. Innov. 2014, 14, 88-107. Available online: http:/ / www.scopus.com/ inward $/$ record.url?eid=2s2.084891132831\&partnerID=40\&md5=a1c7914a47b2e4c53ede234dda6662f9 (accessed on 9 November 2016).

Parrish, K. Lean and green construction: Lessons learned from design and construction of a modular leed ${ }^{\circledR}$ gold building. In Proceedings of 20th Annual Conference of the International Group for Lean, San Diego, CA, USA, 18-20 July, 2012.

Pasquire, C.; Salvatierra-Garrido, J. Introducing the concept of first and last value to aid lean design: Learning from social housing projects in Chile. Archit. Eng. Des. Manag. 2011, 7, 128-138. Available online: http: / / www.scopus.com/inward/record.url?eid=2-s2.0-79959451974\&partnerID=40\&md5= ccac48a040a799abbc448025b2a2f101 (accessed on 12 March 2016).

Riley, D. et al. Lean and Green: The Role of Design-Build Mechanical Competencies in the Design and Construction of Green Buildings. In Proceedings of the Construction Research Congress, San Diego, CA, USA, 5-7 April 2005; American Society of Civil Engineers: Reston, VA, USA; pp. 1-10.

Rosenbaum, S.; Toledo, M.; Gonzalez, V. Improving environmental and production performance in construction projects using value-stream mapping: Case study. J. Constr. Eng. Manage. ASCE 2014, 14, 1-11. Available online: http://ascelibrary.org/doi/abs/10.1061/(ASCE)CO.1943-7862.0000793 (accessed on 9 November 2016). 
Table A2. Cont.

\begin{tabular}{l} 
Papers \\
\hline Rosenbaum, S.; Toledo, M.; Gonzalez, V. Green-lean approach for assessing environmental and production \\
waste in construction. In Proceedings of 20th Annual Conference of the International Group for Lean \\
Construction, San Diego, CA, USA, 2012. \\
Russell-Smith, S.V.; Lepech, M.D.; Fruchter, R.; Meyer, Y.B. Sustainable target value design: integrating life \\
cycle assessment and target value design to improve building energy and environmental performance. \\
J. Clean. Prod. 2014, 88, 43-51, Available online: \\
http:/ / www.sciencedirect.com/science/article/pii/S0959652614002467 (accessed on 10 March 2016).
\end{tabular}

Saggin, A.B. et al. Comparing investments in sustainability with cost reduction from waste due to lean construction. In Proceedings of 23th Annual Conference of the International Group for Lean Construction, Perth, Australia, 29-31 July 2015, pp. 223-232.

Salvatierra-Garrido, J.; Pasquire, C. The first and last value model: Sustainability as a first value delivery of lean construction practice. In Proceedings of 19th Annual Conference of the International Group for Lean, Lima, Peru, 13-15 July 2011, pp. 1-10.

Senaratne, S.; Ekanayake, S. Evaluation of application of lean principles to precast concrete bridge beam production process. J. Archit. Eng. 2012, 18, 94-106.

Song, L.G.; Liang, D.A. Lean construction implementation and its implication on sustainability: a contractor's case study. Can. J. Civil Eng. 2011, 38, 350-359. Available online:

http:/ / www.nrcresearchpress.com/doi/abs/10.1139/L11-005\#.WRNelSvyvIU (accessed on 12 March 2016).

Vasconcelos, I.A. et al. Guidelines for practice and evaluation of sustainable construction sites: a lean, green and wellbeing integrated approach. In Proceedings of 23th Annual Conference of the International Group for Lean Construction, Perth, Australia, 29-31 July 2015, pp. 773-782.

Vieira, A.R.; Cachadinha, N. Lean construction and sustainability-Complementary paradigms? A case study. In Proceedings of 19th Annual Conference of the International Group for Lean Construction, Lima, Peru, 13-15 July 2011, pp. 584-594,

Weinheimer, N. The process of green building certification: an examination regarding lean principles. In Proceedings of Annual Conference of the International Group for Lean Construction, Boston, MA, USA, 2016, pp. 53-62.

Wu, P.; Pienaar, J.; O'brien, D. Developing a lean benchmarking process to monitor the carbon efficiency in precast concrete factories-a case study in Singapore. J. Green Build. 2012, 8, 133-152.

$\mathrm{Wu}, \mathrm{P}$; Feng, Y. Identification of non-value adding activities in precast concrete production to achieve low-carbon production. Archit. Sci. Rev. 2013, 57, 1-10. Available online: http:/ / www.tandfonline.com/doi/abs/10.1080/00038628.2013.829023 (accessed on 4 January 2016).

Wu, P.; Low, S.P.; Jin, X. Identification of non-value adding (NVA) activities in precast concrete installation sites to achieve low-carbon installation. Resources, Conservation and Recycling, v. 81, precast concrete factories-A case study in Singapore. J. Green Build. 2013, 8, 133-152. Available online: http://www.scopus.com/inward/ record.url?eid=2-s2.0-84889101931\&partnerID=40\&md5=1f96652d9bd9909d1b3c22bf077d47c8 (accessed on 4 January 2016).

Wu, P.; Feng, Y. Using lean practices to improve current carbon labelling schemes for construction materials-A general framework. J. Green Build. 2012, 7, 173-191. Available online: http:/ /www.scopus.com/ inward/record.url?eid=2-s2.084859387882\&partnerID=40\&md5=3748f6260e6aeb2b64466fe17ef233c5. (accessed on 4 January 2016)

\section{References}

1. Motta, S.F.R.; Aguilar, M.T.P. Sustainable and design building processes. Des. Manag. Technol. 2009, 4, 84-119. Available online: http://www.iau.usp.br/gestaodeprojetos/index.php/gestaodeprojetos/article/view/ 79/107 (accessed on 4 January 2016).

2. Kibert, C.J. Sustainable Construction-Green Building Design and Delivery, 3rd ed.; John Wiley \& Sons: Hoboken, NJ, USA, 2008.

3. Womack, J.P.; Jones, D.T.; Ross, D. The Machine that Changed the World: The Story of Lean Production; Harper Collins: New York, NY, USA, 1991. 
4. Florida, R.L. Lean and green: The move to environmentally conscious manufacturing. Calif. Manag. Rev. 1996, 39, 80-105. [CrossRef]

5. King, A.A.; Lenox, M.J. Lean and green? An empirical examination of the relationship between lean production and environmental performance. Prod. Oper. Manag. 2001, 10, 244-256. [CrossRef]

6. Vinodh, S.; Arvind, K.R.; Somanaathan, M. Tools and techniques for enabling sustainability through lean initiatives. J. Clean Technol. Environ. Policy 2011, 13, 469-479. [CrossRef]

7. Dües, C.M.; Tan, K.H.; Lim, M. Green as the new Lean: How to use Lean practices as a catalyst to greening your supply chain. J. Clean. Prod. 2013, 40, 93-100. [CrossRef]

8. Wiengarten, F.; Fynes, B.; Onofrei, G. Exploring synergetic effects between investments in environmental and quality/lean practices in supply chains. Int. J. Supply Chain 2013, 18, 148-160. [CrossRef]

9. Dhingra, R.; Kress, R.; Upreti, G. Does lean mean green? J. Clean. Prod. 2014, 85, 1-7. Available online: http:/ / www.sciencedirect.com/science/article/pii/S0959652614010749 (accessed on 28 January 2016).

10. Pampanelli, A.B.; Found, P.; Bernardes, A.M. A Lean \& Green Model for a production cell. J. Clean. Prod. 2014, 85, 19-30. Available online: http:/ /dx.doi.org/10.1016/j.jclepro.2013.06.014 (accessed on 28 January 2016).

11. Verrier, B.; Rose, B.; Caillaud, E.; Remita, H. Combining organizational performance with sustainable development issues: The Lean and Green project benchmarking repository. J. Clean. Prod. 2014, 85, 83-93. [CrossRef]

12. Garza-Reyes, J.A. Lean and green-A systematic review of the state of the art literature. J. Clean. Prod. 2015, 102, 18-29. Available online: http:/ /dx.doi.org/10.1016/j.jclepro.2015.04.064 (accessed on 28 January 2016). [CrossRef]

13. Horman, M.J.; Riley, D.R.; Lapinski, A.R.; Korkmaz, S.; Pulaski, M.H.; Magent, C.S.; Luo, Y.; Harding, N.; Dahl, P.K. Delivering green buildings: Process improvements for sustainable construction. J. Green Build. 2006, 1, 123-140. Available online: http:/ / www.scopus.com/inward/record.url?eid=2-s2.0-33646746735\& partnerID=40\&md5=a530c0a1d5df35972714341f693ff6fd (accessed on 10 February 2016). [CrossRef]

14. Bae, J.W.; Kim, Y.W. Sustainable value on construction projects and lean construction. J. Green Build. 2008, 3, 155-167. Available online: http:/ / www.scopus.com/inward/record.url?eid=2-s2.0-77953336155\& partnerID=40\&md5=3eda2cd491661864136f1579c80c0ded (accessed on 10 February 2016). [CrossRef]

15. Khodeir, L.M.; Othman, R. Examining the interaction between lean and sustainability principles in the management process of AEC industry. Ain Shams Eng. J. 2016. Available online: http://www.sciencedirect. com/science/article/pii/S2090447916301769 (accessed on 20 January 2017). [CrossRef]

16. Cooper, H.M. Synthesizing Research: A Guide for Literature Reviews, 3rd ed.; SAGE Publications, Inc.: Thousand Oaks, CA, USA, 1998.

17. Tranfield, D.; Denyer, D.; Smart, P. Towards a Methodology for Developing Evidence-Informed Management Knowledge by Means of Systematic Review. Br. J. Manag. 2003, 14, $207-222$. Available online: http://www.scopus.com/inward/record.url?eid=2-s2.0-0141888108\&partnerID=40\& md5=ac698a820262699003a609df52c42dfa (accessed on 4 January 2016). [CrossRef]

18. Biernack, P.; Waldorf, D. Snowball Sampling: Problems and techniques of chain referral. Sociol. Methods Res. 1981, 10, 141-163.

19. Heckathorn, D.D. Comment: Snowball versus respondent-driven sampling. Sociol. Methodol. 2011, 41, $355-366$. Available online: http:/ / doi.wiley.com/10.1111/j.1467-9531.2011.01244.x (accessed on 9 November 2016). [CrossRef] [PubMed]

20. Kitchenham, B.; Charters, S. Guidelines for performing Systematic Literature Reviews in Software Engineering. In Technical Report EBSE 2007-001; Keele University and Durham University Joint Report, Keele University and University of Durham: Staffordshire; Durham, UK, 2007.

21. Elkington, J. Cannibals with Forks: The Triple Bottom Line of 21st Century Business; Capstone: Mankato, MN, USA, 1997.

22. Huovila, P.; Koskela, L. Contribution of the principles of lean construction to meet the challenges of sustainable development. In Proceedings of the 6th Annual Conference of the International Group for Lean Construction, Guarujá, Brazil, 13-15 August 1998; pp. 1-11.

23. Carneiro, S.B.M.; Campos, I.B.; Oliveira, D.M.; Barros Neto, J.P. Lean and green: A relationship matrix. In Proceedings of the 20th Annual Conference of the International Group for Lean, San Diego, CA, USA, 18-20 July 2012. 
24. Lapinski, A.R.; Horman, M.J.; Riley, D.R. Lean processes for sustainable project delivery. J. Constr. Eng. Manag. 2006, 132, 1083-1091. [CrossRef]

25. Horman, M.J.; Riley, D.R.; Pulaski, M.H.; Leyenberger, C. Lean and Green: Integrating Sustainability and Lean Construction. In Proceedings of the 16th CIB World Building Congress, Toronto, ON, Canada, 7 May 2004; pp. 1-10.

26. Lapinski, A.; Horman, M.; Riley, D. Delivering sustainability: Lean principles for green projects. In Proceedings of the Construction Research Congress, San Diego, CA, USA, 5-7 April 2005; American Society of Civil Engineers: Reston, VA, USA, 2012; pp. 53-62.

27. Degani, C.M.; Cardoso, F.F. Environmental Performance and Lean Construction Concepts: Can We Talk about A 'Clean Construction'. In Proceedings of the 10th Annual Conference of the International Group for Lean Construction, Gramado, Brazil, 6-8 August 2002; pp. 1-12.

28. Bae, J.W.; Kim, Y.W. Sustainable value on construction project and application of lean construction methods. In Proceedings of the 15th Annual Conference of the International Group for Lean, East Lansing, MI, USA, 18-20 July 2007; pp. 312-321.

29. Golzarpoor, H.; González, V. A Green-Lean Simulation Model for Assessing Environmental and Production Waste in Construction. In Proceedings of the 21th Annual Conference of the International Group for Lean Construction, Fortaleza, Brazil, 29 July-2 August 2013; pp. 885-894.

30. Vieira, A.R.; Cachadinha, N. Lean construction and sustainability-Complementary paradigms? A case study. In Proceedings of the 19th Annual Conference of the International Group for Lean Construction, Lima, Peru, 13-15 July 2011; pp. 584-594.

31. Ahuja, R. Sustainable construction: Is lean green? Proceedings of International Conference on Sustainable Design, Engineering, and Construction, Fort Worth, TX, USA, 7-9 November 2012.

32. Jeong, W.; Chang, S.; Son, J.-S.; Yi, J. BIM-integrated construction operation simulation for just-in-time production management. Sustainability 2016, 8, 1106. [CrossRef]

33. Saggin, A.B.; Valente, C.P.; Mourão, C.A.M.A.; Cabral, A.E.B. Comparing investments in sustainability with cost reduction from waste due to lean construction. In Proceedings of the 23th Annual Conference of the International Group for Lean Construction, Perth, Australia, 29-31 July 2015; pp. 223-232.

34. Jacomit, A.M.; Silva, V.G.; Granja, A.D. Can sustainable buildings cost the same as conventional buildings? In Proceedings of the 3rd CIB International Conference on Smart and Sustainable Built Environments, Delft, The Netherlands, 15-19 June 2009; pp. 1-8.

35. Kats, G.H. Green Building Costs and Financial Benefits; Massachusetts Technology Collaborative: Westborough, MA, USA, 2003; pp. 1-8.

36. Matthiessen, F.; Morris, P. Costing Green: A Comprehensive Cost Database and Budgeting Methodology; U.S. Green Building Council: Washington, DC, USA, 2004.

37. Morris, P. What Does Green Really Cost? The Green Issue Feature; PREA Quarterly Summer: Hartford, CT, USA, 2007; pp. 55-60.

38. Kats, G. Tornando Nosso Ambiente Construído Mais Sustentável-Custos, Benefícios e Estratégias; Island Press: Washington, DC, USA, 2010. Available online: http://www.secovi.com.br/files/Downloads/livro-tornandonosso-ambiente-construido-mais-sustentavel-greg-katspdf.pdf (accessed on 9 July 2016). (In Portuguese)

39. Rehm, M.; Ade, R. Construction costs comparison between 'green' and conventional office buildings. Build. Res. Inf. 2013, 41, 198-208. Available online: http://www.tandfonline.com/doi/abs/10.1080/ 09613218.2013.769145\#.Vvl5nuIrLIU (accessed on 9 July 2016). [CrossRef]

40. Mathiessen, L.F.; Morris, P. The Cost of Green Revisited: Reexamining the Feasibility and Cost Impact of Sustainable Design in the Light of Increased Market Adoption; Davis Langdon: New York, NY, USA, 2007.

41. Riley, D.; Sanvido, V.; Horman, M.; McLaughlin, M. Lean and Green: The Role of Design-Build Mechanical Competencies in the Design and Construction of Green Buildings. In Proceedings of the Construction Research Congress, San Diego, CA, USA, 5-7 April 2005; American Society of Civil Engineers: Reston, VA, USA; pp. 1-10.

42. Koskela, L. An Exploration Towards a Production Theory and Its Application to Construction; VTT Publications, Technical Research Centre of Finland: Espoo, Finland, 2000; p. 296. 
43. Pasquire, C.; Salvatierra-Garrido, J. Introducing the concept of first and last value to aid lean design: Learning from social housing projects in Chile. Archit. Eng. Des. Manag. 2011, 7, 128-138. Available online: http:/ / www.scopus.com/inward/record.url?eid=2-s2.0-79959451974\&partnerID=40\& md5=ccac48a040a799abbc448025b2a2f101 (accessed on 12 March 2016). [CrossRef]

44. Salvatierra-Garrido, J.; Pasquire, C. The first and last value model: Sustainability as a first value delivery of lean construction practice. In Proceedings of the 19th Annual Conference of the International Group for Lean, Lima, Peru, 13-15 July 2011; pp. 1-10.

45. Vasconcelos, I.A.; Candido, L.F.; Heineck, L.F.M.; Neto, J.P.B. Guidelines for practice and evaluation of sustainable construction sites: A lean, green and wellbeing integrated approach. In Proceedings of the 23th Annual Conference of the International Group for Lean Construction, Perth, Australia, 29-31 July 2015; pp. 773-782.

46. Koskela, L. Application of the new production philosophy to construction. In Technical Report \#72; Center for Integrated Facility Engineering (CIFE), Stanford University: Stanford, CA, USA, 1992.

47. Maris, K.; Parrish, K. The confluence of lean and green construction practices in the commercial buildings market. In Proceedings of the Annual Conference of the International Group for Lean Construction, Boston, MA, USA, 20-22 July 2016; pp. 43-52.

48. Ogunbiyi, O.; Oladapo, A.; Goulding, J. An empirical study of the impact of lean construction techniques on sustainable construction in the UK. Constr. Innov. 2014, 14, 88-107. Available online: http:/ / www.scopus.com/ inward $/$ record.url?eid=2s2.084891132831\&partnerID=40\&md5=a1c7914a47b2e4c53ede234dda6662f9 (accessed on 9 November 2016). [CrossRef]

49. Castro-Lacouture, D.; Ospina-Alvarado, A.M.; Roper, K.O. AEC+P+F integration with green project delivery and lean focus. J. Green Build. 2008, 3, 154-169. Available online: http://www.scopus.com/inward/ record.url?eid=2-s2.0-77953332834\&partnerID=40\&md5=df67cdbc42d53307d2ca46551864be5e (accessed on 9 July 2016). [CrossRef]

50. Picchi, F. System view of lean construction application opportunities. In Proceedings of the 9th Annual Conference of the International Group for Lean Construction, Singapore, 6-8 August 2001.

51. Standardization, E.C.F. EN 15978: Sustainability of Construction Works: Assessment of Environmental Performance; BSI: Brussels, Belgium, 2011.

(C) 2017 by the authors. Licensee MDPI, Basel, Switzerland. This article is an open access article distributed under the terms and conditions of the Creative Commons Attribution (CC BY) license (http:/ / creativecommons.org/licenses/by/4.0/). 